\title{
SOVEREIGNTY AND RACE AS AFFECTED BY A LEAGUE OF NATIONS
}

\section{By Theodore Marburg,}

\author{
Formerly United States Minister to Belgium.
}

Just as the old idea of natural rights has given way to the conception that the state has a right to do whatever it is in the interest of society in the long result that it should do, so it is becoming plain that the doctrine of absolute sovereignty set up to guard the state itself against interference by other states must ultimately give way before the conception of a society of nations. As is well known, the theory of natural rights, which set boundaries to the activities of the state operating on its own people, was designed to protect men against the power of the autocrat. When governments came to reflect the will of the people the need for this device disappeared. The doctrine of absolute sovereignty had its origin in a similar motive. The theory was designed to safeguard the right of the individual state in a world where the powerful state was governed by few rules or precepts and was moved principally by the desire for aggrandizement. As democracy spreads, the dominating motive of aggrandizement is diminished and the desire to do justice to the sister state begins to emerge. When this happens the same ultimate test may be applied to the doctrine of sovereignty as was applied to the doctrine of natural rights.

If it is in the interests of men that nations should enjoy sovereignty full and unimpaired, well and good. If, on the contrary, sovereignty unimpaired leads to disaster-in the shape, for example, of unjust and destructive wars-it should not be suffered to continue. The state should retain only so much sovereignty as makes for the welfare of men organized in states.

The experience of the forty-eight states now comprising the United States of America is really an application of this conception. The Union was constituted of sovereign and independent states. They surrendered sovereignty but not self-government. The separate states of the Union still govern themselves with respect 
to three quarters of the things that touch the public interest. Absolute sovereignty was surrendered by them in the common interest.

Now, world opinion is not ripe for a union of the nations so complete as the union of the American states under a federal government. But even a rudimentary organization must be based upon this same conception, namely, the right of the society of nations to demand of the individual states whatever it is in the interest of the race that they should demand.

Within the state the individual without wealth or influence who, in former times, was preyed upon by the powerful, now enjoys, under modern institutions, the same rights and privileges before the law as the wealthy and powerful. Just so, under a properly organized society of nations, the small state will come to enjoy security equal to that of its more powerful neighbor, a security far more ample than any doctrine of absolute sovereignty can give it under present conditions.

Society implies restraint. We can have no liberty without a surrender of license. The one license which it has become perfectly clear the nations must surrender is the license to make war at will. Begin with that demand, make it difficult for nations to settle disputes by force, and they will seek and find other ways to settle them. That truth is at the very bottom of the whole movement for world organization. If we take our stand upon that demand the machinery for settling disputes will come.

In this connection a few words must be said about the question of race and alien government. Certain groups, such as the Netherlands Anti-Oorlog Raad, demand a plebiscite of the inhabitants before a transfer of territory is permitted. Theoretically this would seem to fit in with the demands of justice. Practically, serious difficulties present themselves in connection with the proposal.

In the first place, to admit this right of approval by the population of the territory about to be transferred involves logically the right of secession. Suppose, for example, that at the end of this war the people of Alsace are consulted about restitution of the province to France, that they should approve of it and that the transfer is thereupon made. If, then, at a future time, these same people of Alsace should reach the conclusion that they had 
made a mistake and should demand release from their allegiance to France, could this demand logically be denied? And are we prepared to admit the right of secession whenever a local community exhibits discontent under a government? To have set up such a principle would have conceded the right of the New England States to secede from the American Union when the several waves of discontent swept over them at the end of the eighteenth century and in the early years of the nineteenth century. It would have admitted the right of the Southern States to secede when the slavery issue became acute. It would admit the right of Ireland today to secede from Great Britain and to establish, close to the border of the home country, a separate sovereignty which might afford a foothold for an enemy attack.

Peace is secured by union, not by disruption. For generations the border of England and Scotland was the scene of bloody strife, all stilled by the union of these two countries in 1707. For fourteen hundred years after the fall of the Roman Empire of the west, Italy was torn by ceaseless wars between her city states and between her principalities, leaving her an easy prey to the invader-all stilled by union. The mind of Cavour grasped this truth firmly and laid broad the foundations for a single Italian State which has spelled rebirth, security and progress.

For centuries men witnessed similar wars between the principalities and petty kingdoms of France. It was the very establishment of strong central government in France at an early day which enabled her to shine as a leader in Europe in all the walks of civilization.

In Germany for long years the hand of every baron and petty noble was turned against his neighbor. There too it was consolidation which brought law and ordered progress.

In the second place the plebiscite is often a meaningless form. Certainly it has been such in France, where it has been used to confirm a fait accompli. For the people to endeavor to undo the thing already done would have meant anarchy. Therefore the result has usually been millions of affirmative votes against a few thousand negative votes. Napoleon Bonaparte made himself first Consul in December, 1799, organized his government and six weeks thereafter instituted a plebiscite to confirm his act. Is there any need to say what the result of that plebiscite was? When in 
May, 1804, he had safely gotten the title of Emperor conferred on him by the Senate he again invited a plebiscite with like result. Louis Napoleon was not slow to see the advantages of this method. A plebiscite, December 20, 1851, endorsed his high-handed metnods of dealing with the National Assembly and of perpetuating himself as President of the Republic in violation of the provisions of the Constitution. Next, having gathered into his hands all executive power with the right to nominate the members of the Senate and of the Council of State, through which alone legislation could be initiated, he proceeded once more to institute a plebıscite which conferred on him the title of Emperor.

Now, is not the question of a transfer of territory in much the same category? Such transfer at the end of a war has to be agreed upon in framing the treaty of peace. For the people of the territory in question to negative the decision of the Congress might mean reopening the vital issues of the war and so renewing the war. Under such circumstances, is there any doubt that the votes of the inhabitants will simply register what the Congress has decreed? At such times, too, the men "in possession" generally get their will done. Dicey refers to the way in which, during the French Revolution, "the Terrorist faction, when all but crushed by general odium, extorted from the country by means of a plebiscite a sham assent to the prolongation of revolutionary despotism."

The real solution of the problem of race conflict lies in equal political rights for all white men in white men's countries. If the Johannesburger had enjoyed the full franchise under the Boer government the injustice practised against him would have been impossible and the South African War would not have occurred. When men everywhere come to enjoy equal political rightsenabling them to help themselves to full civil rights and religious liberty-they will in course of time cease to care whether they live under this or that government.

Discontent will further tend to disappear if we add to this the system of local self-government such as obtains in the United States, where the people of the separate states govern themselves in respect of the majority of things that touch their interests.

A league of nations to discourage war is almost certain to come into being after the present conflict, because the Entente Powers, in their joint note of January 10 to Mr. Wilson, committed 
themselves formally and officially to the project. But, until it is shown that the league can and will protect its members against sudden assault, until it is shown that the league itself will hold together in times of storm and stress, no country can be expected to place its sole reliance for protection on it. Until then, Great Britain, for example, could not in fairness be asked to impair the strength of her great fleet.

An important line of progress in the history of war has been the tendency to spare the non-combatant and confine the conflict to the armed forces of the belligerents. These helpful rules of war, so painfully bought by experience and laboriously worked out through generations of endeavor, Germany has thrown to the winds. And she has not stopped there. Deeds which men, relying upon the common dictates of humanity, thought it wholly unnecessary specifically to forbid, have been done, not in the heat of battle, but deliberately as part of a conscious policy. Others among the belligerents are not free from blame for giving way to the temptation to retaliate. But in their case we behold the spawn of an uncontrollable rage excited by the acts of the enemy.

To many men the crimes committed in this war, the very assault itself, were, before the event, simply unbelievable. The result is a shock to confidence-confidence in the binding force of treaty obligations, confidence in international law, and confidence in the upright intentions of the neighbor. No matter what the issue of the war, we are therefore apt, for a time, to witness armaments going on at an accelerated pace. But once the German menace is definitely removed by a change of spirit on the part of the German people, the world may not only work back to its normal condition, but the existence of a league of nations-after it shall have established general confidence in its ability to do what it is designed to do-must eventually bring about an actual amelioration of the condition of armed peace existing before the present war. To the security due to the geographical position which some nations enjoy, and to their individual preparedness, states will then add the security of a guarantee by the family of nations against sudden attack. 